\title{
Movements and mortality of two commercially exploited carcharhinid sharks following longline capture and release off eastern Australia
}

\author{
Christopher J. Barnes ${ }^{1}$, Paul A. Butcher ${ }^{1,2, *}$, William G. Macbeth ${ }^{3}$, \\ John W. Mandelman ${ }^{4}$, Stephen D. A. Smith ${ }^{1}$, Victor M. Peddemors ${ }^{5}$ \\ ${ }^{1}$ National Marine Science Centre, Southern Cross University, PO Box 4321, Coffs Harbour, New South Wales 2450, Australia \\ ${ }^{2}$ Fisheries NSW, NSW Department of Primary Industries, National Marine Science Centre, PO Box 4321, Coffs Harbour, \\ New South Wales 2450, Australia \\ ${ }^{3}$ FERM Services (Fisheries and environmental consultant), PO Box 337, Sheffield, Tasmania 7306, Australia \\ ${ }^{4}$ John H. Prescott Marine Laboratory, New England Aquarium, Boston, Massachusetts 02110, USA \\ ${ }^{5}$ Fisheries NSW, Department of Primary Industries, Sydney Institute of Marine Science, Mosman, New South Wales 2088, \\ Australia
}

\begin{abstract}
Carcharhinus plumbeus (sandbar shark) and C. obscurus (dusky shark) occur in many global fisheries as targeted species and/or bycatch. However, little is known about their movement and the possible fate of discards. We redressed this lack of knowledge using pop-up satellite archival tags (PSAT) and acoustic tagging technologies off the eastern coast of Australia. Eight sharks of each species were caught by demersal longline, fitted with both types of tag and then released. PSATs indicated that 2 C. plumbeus and 1 C. obscurus died within $8 \mathrm{~h}$ of release, while tracks over periods of 1 to $60 \mathrm{~d}$ were obtained for 13 sharks. All surviving sharks first swam in an easterly, offshore direction to outer-shelf waters during the first $24 \mathrm{~h}$. All C. plumbeus then moved approximately south (i.e. increasing latitude) by distances of up to $\sim 350 \mathrm{~km}$. In contrast, most C. obscurus moved approximately north by distances between 212 and $606 \mathrm{~km}$. Over an 18 mo period following release, acoustic tag detections occurred for 4 C. plumbeus (mostly within $30 \mathrm{~km}$ of release, suggesting some philopatry) and 6 C. obscurus $(\sim 515 \mathrm{~km}$ south and $\sim 310 \mathrm{~km}$ north). Both species spent $\sim 85 \%$ of their time in waters $<100 \mathrm{~m}$ deep. Diel patterns in vertical movements of C. plumbeus were detected, with a preference for deeper water during daylight hours. Both species mainly utilised water temperatures between 22 and $26^{\circ} \mathrm{C}$. Information from this study can be used for the effective management of commercially exploited stocks of both species.
\end{abstract}

KEY WORDS: Carcharhinid $\cdot$ Satellite tag $\cdot$ Acoustic tag $\cdot$ Hook timer $\cdot$ Hooking mortality

\section{INTRODUCTION}

Global shark fisheries often follow patterns of 'boom and bust', with stock depletion ensuing rapidly after the onset of intensive fishing (Baum et al. 2003, Dulvy et al. 2008). Large shark species, such as

${ }^{*}$ Corresponding author: paul.butcher@dpi.nsw.gov.au many carcharhinids (i.e. requiem or 'whaler' sharks), sphyrnids (i.e. hammerheads) and lamnids (i.e. mackerel sharks), are typically long-lived and characterised by slow growth, late maturity and very low fecundity (Musick 1999, Frisk et al. 2001). Such characteristics lead to low rates of population increase/

() The authors 2016. Open Access under Creative Commons by Attribution Licence. Use, distribution and reproduction are unrestricted. Authors and original publication must be credited. 
recovery (Smith et al. 1998, Reynolds et al. 2005) and, therefore, decreased capacity to withstand sustained fishing mortality (Stevens et al. 2000, Musick 2004). If recovery of such populations is possible following severe depletion, it often takes decades to achieve (Smith et al. 1998, Morgan et al. 2009). Nevertheless, past studies have indicated that some shark species can be harvested sustainably and provide stable fisheries if carefully managed (Simpfendorfer 1999, Musick 2004).

In Australia, there are a number of established, separately managed fisheries for carcharhinids in waters around the continent (Simpfendorfer 1999, Harry et al. 2011). Despite most of these fisheries involving theoretically sustainable targeting of sizes below sexual maturity, overfishing is still a potential threat. In the northern half of the state of New South Wales (NSW) on the eastern coast, large adult carcharhinids have, since the mid-2000s, been commercially targeted and caught via a demersal longline sub-fishery within the Ocean Trap and Line Fishery (OTLF), primarily for their fins. By law, the headless, gutless and finless carcasses are also required to be retained and sold. With little known about the species composition of catches, a precautionary approach was adopted in 2008 with the implementation of a conservative total allowable catch (TAC) of 160 tonnes (further reduced to 126.5 tonnes in 2009) (Macbeth et al. 2009). However, this measure not only increased potential for discarding but also represented an estimated 3-fold decrease in the value of the sub-fishery to local economies (Harrison 2010). Given these superficially conflicting interests, the lack of scientific data underpinning TAC establishment highlighted the need for urgent advancements in the biological knowledge used to refine them.

Observer-based research in 2008/09 indicated the 2 species most frequently caught in the OTLF largeshark sub-fishery were Carcharhinus plumbeus (sandbar shark, $35 \%$ of all captures during observed fishing trips) and C. obscurus (dusky shark, 15\%) (Macbeth et al. 2009). Further, the vast majority of catches of these species comprised sharks across their entire reproductively capable size ranges of $160-220 \mathrm{~cm}$ and $290-380 \mathrm{~cm}$ total length (TL), respectively. Globally, catch rates of both species have gradually declined in more established fisheries which target relatively large sharks, despite intensive catch monitoring and long-term fishery management (Morgan et al. 2009, Romine et al. 2009).

C. plumbeus and C. obscurus populations are each widely, but discontinuously, distributed throughout the warm temperate to tropical (and temperate in the case of $C$. obscurus) waters of the world, including the west and east coasts of Australia (Last \& Stevens 2009). Research in Australian waters has indicated that, for both species, the east and west coast populations are genetically distinct and in fisheries terms should be considered separate stocks (McAuley et al. 2007, Geraghty et al. 2014). Both are long-lived (up to 40 and $55 \mathrm{yr}$, respectively), grow very slowly $\left(k<0.17 \mathrm{yr}^{-1}\right)$, reach sexual maturity at old ages (range of estimates: 8-15 and 17-32 yr, respectively), have low fecundity $\left(<15\right.$ pups litter $\left.^{-1}\right)$ and have relatively long gestation and inter-litter periods (up to 2 yr) (Simpfendorfer et al. 2002, McAuley et al. 2007, Romine et al. 2006, 2009). These life-history parameters combine to result in low intrinsic rates of population increase and make both species highly vulnerable to anthropogenic pressures and overexploitation (Sminkey \& Musick 1995, Brewster-Geisz \& Miller 2000).

Large-scale seasonal, temperature-related migrations of adults and large juveniles of both species are known to occur along continental coastlines of the USA (Kohler et al. 1998, Grubbs et al. 2007, Hoffmayer et al. 2014), South Africa (Hussey et al. 2009) and Australia (Rogers et al. 2013). In contrast, some populations of $C$. plumbeus have been found to permanently reside in 1 location throughout the year (e.g. Red Sea: Baranes \& BenTuvia 1978; China Sea and Taiwan: Joung \& Chen 1995; Hawaii: DalyEngel et al. 2007). In Western Australia (WA), migration of adults from tropical to temperate latitudes was detected in autumn months, with males thought to typically travel in large schools while females migrate individually or in small groups (McAuley et al. 2007). These migrations may take place in response to changes in currents, water temperature, breeding cycles or food availability (Compagno 1984). Although both species have been studied in some detail across their distribution, little is known about their movements and habitat preferences along the east coast of Australia. Improved understanding of key aspects of the local ecology of the 2 species might help to inform decisions on spatio-temporal initiatives such as marine protected areas for specific nursery and reproduction areas or time-area closures and reductions in TAC during aggregation or migration (Speed et al. 2010).

Declining populations of important commercial species worldwide have led fisheries managers to introduce quotas and retention limits, such as those imposed for sharks in the OTLF, which commonly result in the discarding of many captured sharks (Gilman et al. 2008). Physical trauma and physiologi- 
cal stress caused by hooking can result in acute and chronic effects, potentially leading to unaccounted mortality once the fish is released (Skomal 2007). As is the case for incidental catch in fisheries in general, cryptic mortality of sharks can hold considerable ecological, management and conservation implications and is of dire importance to the proper management of direct or incidental shark fisheries (Gilman et al. 2013).

Given the above, the objectives of this study were to use satellite and acoustic tagging technologies to (1) identify and quantify vertical and horizontal movements of tagged C. obscurus and C. plumbeus, along with the key environmental parameters possibly influencing these behaviours, and (2) estimate the post-release mortality associated with capture of these species by a commercial demersal longline.

\section{MATERIALS AND METHODS}

Targeted demersal longlining for Carcharhinus obscurus and C. plumbeus was conducted from chartered commercial fishing vessels in NSW continental-shelf waters between the latitudes of $29^{\circ} 56^{\prime} \mathrm{S}$ and $30^{\circ} 34^{\prime} \mathrm{S}$ and within $\sim 20 \mathrm{~km}$ of the coast, over $9 \mathrm{~d}$ between March and July 2013. All fishing was undertaken using a longline configuration that is commonly used in this fishery to target sharks (Macbeth et al. 2009). This system consisted of a $3.2 \mathrm{~mm}$ weighted monofilament mainline with 480 gangions set $20 \mathrm{~m}$ apart. Every $3.6 \mathrm{~m}, 400 \mathrm{~kg}$ monofilament gangion terminated in a 16/0 non-offset circle hook baited with $0.3 \mathrm{~kg}$ of sea mullet Mugil cephalus and incorporated a digital hook timer (HT 600, LindgrenPitman; Sigler 2000) to record the time elapsed between each shark being hooked and hauled back to the vessel (time on hook). Lines were set over a sandy substrate in 50 to $105 \mathrm{~m}$ of water and then retrieved after a minimum gear deployment of $7 \mathrm{~h}$. Bottom and surface sea water temperatures $\left({ }^{\circ} \mathrm{C}\right)$ were recorded every 30 min by 8 loggers (Vemco, Nova Scotia, Canada) attached along the mainline and to surface floats.

Following haulback, sharks were brought alongside the boat and onto the deck via a sea door. The physical condition of all sharks was assessed using the condition index for post-capture survival from Braccini et al. (2012), with only those that had a high or medium score considered for tagging. A deck hose was then immediately inserted into the shark's mouth to ensure seawater flow $\left(201 \mathrm{~min}^{-1}\right)$ was maintained over the gills, and a wet towel was placed over the shark's eyes to control stress while research activities were performed (Violetta 2004). Hooks were removed from the shark's mouth. Sharks assessed to be moribund or rated as having a low score for 'activity and stimuli' (Braccini et al. 2012) were retained by the commercial fishers, while all live sharks (tagged or otherwise) were released following collection of various biological data and samples (<5 min). Those not displaying signs of spontaneous, independent movement on return to the water were maintained in position alongside the moving boat for up to 5 min to allow further recovery prior to release.

\section{Tagging methodology}

Eight C. obscurus and 8 C. plumbeus were each fitted with an external pop-up satellite archival tag (PSAT) (MiniPATs; Wildlife Computers), internal acoustic transmitter tag (V16-6L, Vemco) and external identification tag (orange plastic, nylon-head dart-tag; Hallprint Pty, South Australia). Each PSAT was connected to its host via a corrodible attachment link to a heat-shrink-wrapped, stainless-steel tether and nylon 'Domeier' umbrella dart tag (with attached Dacron; Domeier et al. 2005, Rogers et al. 2013). The umbrella dart was inserted using applied force to a tagging pole so that the dart tip was embedded 8 to $10 \mathrm{~cm}$ into the dorsal musculature just lateral to the posterior end of the first dorsal fin (Campana et al. 2011, Queiroz et al. 2012). The corrodible attachment link was designed to detach the tag from the tether following a pre-programmed deployment period of $100 \mathrm{~d}$ or when the tag had been at a constant depth \pm $2.5 \mathrm{~m}$ (to account for tidal range) for $4 \mathrm{~d}$ (indicating likely death of the host; Campana et al. 2011). If either conditional detachment parameter was met, the link dissolved, detaching the tag to float to the surface and commence transmission of data to Advanced Research and Global Observation Satellites (ARGOS). An additional, pressure-activated mechanical guillotine detachment device (RD1800; Wildlife Computers) was included to immediately cut the tether if depth exceeded $1700 \mathrm{~m}$, ensuring that the PSATs would be detached before reaching damaging depths.

A small acoustic transmitter (V16-6L, Vemco) was surgically implanted into the abdominal cavity of each shark following the general procedure of Heupel et al. (2006). The transmitters emit a unique sequence at a frequency of $69 \mathrm{kHz}$ that repeats after a random delay of 40 to $80 \mathrm{~s}$ (nominal $60 \mathrm{~s}$ ) for $3650 \mathrm{~d}$ $(10 \mathrm{yr})$. Signals were tracked by an array of passive 
listening stations currently positioned around the Australian coast and continental shelf; most are part of the Integrated Marine Observing System (IMOS) Animal Tracking Facility, with some maintained as private research instruments by various researchers. Unique, sequentially numbered identification tags were inserted into the musculature just below the first dorsal fin of tagged sharks to signify the presence of the internal acoustic transmitters and aid identification during any subsequent recapture (Butcher et al. 2010).

\section{Data collection}

Prior to release, sharks were measured for pre-caudal (PCL), fork (FL) and total (TL) length, while the location, date and time of capture haulback, time on hook (provided by hook timers), hook number, anatomical hooking location, sex and status (alive/ dead) were also recorded.

Summary data obtained from PSATs via satellite comprised depth-temperature profiles (time series recorded at 5 min intervals), time-at-depth and timeat-temperature histograms, percentage of time spent in the mixed layer (i.e. uniform temperature layer of surface waters) and light-level curves. Recovered PSATs allowed more detailed analysis of the entire archived dataset, which included data recorded every $3 \mathrm{~s}$ in addition to the summary data (Hoolihan et al. 2011). Positions of sharks between attachment and tag pop-up were estimated using light-level data to estimate sunset and sunrise times and thereby calculate latitude and longitude. While providing precise longitudinal positioning throughout the year, latitudinal errors of $1^{\circ}$ to $5^{\circ}$ can occur, with the level of imprecision dependent on water clarity, vertical behaviour of the shark and time of year (Nielsen \& Sibert 2007, Lam et al. 2010). Supplementary positional data recorded by the relevant acoustic listening stations were downloaded and stored via either the IMOS management system (open access) or by independent researchers, with data ultimately provided by IMOS and the cooperative independent researchers.

\section{Data analysis}

Light-based geolocation readings provided by PSATs were processed using software to correct errors in sunset/sunrise times and produce geolocation estimates (WC-DAP 3.0 and WC-GPE2, Wildlife
Computers). These data were processed by Collecte Localisation Satellite (CLS) using the 'Track and Loc' program, which uses a random-walk model based on maximum horizontal velocity with a diffusion coefficient of $1000 \mathrm{~km}^{2} \mathrm{~d}^{-1}$ to reduce the impact of lightderived positional error (Royer \& Lutcavage 2009). Additional constraints were provided by validation of PSAT data concerning shallow water temperatures against satellite-derived sea surface temperatures (Operational Sea Surface Temperature and Sea Ice Analysis [OSTIA]) (Teo et al. 2004) as well as maximum daily depths obtained by sharks against bathymetry from the Earth Topography (ETOPO) digital dataset. The above information was assembled in the framework of an Ensemble Kalman filter (ENSKF), allowing the algorithm to exclude non-relevant points and determine the most likely track taken by each shark between tag deployment and detachment (Royer et al. 2005, Royer \& Lutcavage 2009). Application of this method was limited to tags that detached at least $50 \mathrm{~km}$ from the deployment location and where sufficient transmissions were received by ARGOS satellites.

For each tagged shark, temperature and depth data collected by PSATs were analysed to identify possible relationships between movement behaviour and environmental variables. To investigate diel patterns in vertical movement, behaviour and habitat utilisation, temperature and depth datasets were separated into periods of night (18:00 to 06:00 h) and day (06:00 to 18:00 h). Two-sample KolmogorovSmirnov (KS) tests were then used to compare between night and day distributions for depth and temperature.

\section{RESULTS}

Environmental conditions in the study area were relatively consistent throughout the longlining/tagging period: seas and swell ranged from 0.5 to $1.5 \mathrm{~m}$; currents generally flowed to the south at a mean $\pm \mathrm{SD}$ of $0.6 \pm 0.2$ nautical miles per hour; and water temperatures at the surface and bottom were $23.8 \pm$ $0.5^{\circ} \mathrm{C}$ and $21.2 \pm 0.4^{\circ} \mathrm{C}$, respectively.

Of the 281 individuals caught, 93.9\% were from 13 species of shark, with Carcharhinus plumbeus and $C$. obscurus representing 22\% (ranked 1st: 61 individuals) and 14\% (ranked 3rd: 39 individuals) of the total catch, respectively. Sharks to be tagged were in good condition and selected from non-moribund individuals: 4 male and 4 female $C$. plumbeus (selected from 28 live individuals), and 5 male and 3 
female C. obscurus (selected from 11 live individuals) (Table 1). For all individuals, condition index scores for the probability of survival for each shark were 'high' following examination for (1) wounds and bleeding, (2) skin damage and bruising and (3) damage from lice. Similarly, all but 1 dusky (D3) and 1 sandbar (S2) shark (both rated as 'medium') were scored as 'high' for activity and stimuli.

All sharks were mouth-hooked. Sizes of tagged sharks ranged from 184 to $223 \mathrm{~cm}$ TL for C. plumbeus (mean \pm SD of $204.1 \pm 13.4 \mathrm{~cm} \mathrm{TL}$ ) and from 209 to $362 \mathrm{~cm}$ TL $(310.4 \pm 56.1 \mathrm{~cm})$ for C. obscurus (Table 1). Based on reported TLs at maturity for male and female C. plumbeus $(>150 \mathrm{~cm}$ and $>160 \mathrm{~cm}$, respectively) and $C$. obscurus (>250 $\mathrm{cm}$ and $>285 \mathrm{~cm}$, respectively), 14 of the 16 sharks tagged were estimated to be adults, while the remaining 2 sharks were estimated to be sub-adult C. obscurus (D2 and D4; Table 1). Time on hook for the sharks ultimately tagged was highly variable, ranging (in h:min) from 3:30 to 14:54 for C. plumbeus and from 1:33 to $18: 12$ for C. obscurus (Table 1).

\section{Post-release mortality}

Three tagged sharks (2 sandbar and 1 dusky) appeared to have died shortly following release and within the general vicinity of their capture and release sites. The PSATs from these 3 sharks recorded a period of $\geq 4 \mathrm{~d}$ at constant depth after which auto-detachment of the PSATs occurred $(3.5 \mathrm{~h}$ after release for $\mathrm{S} 7,6.0 \mathrm{~h}$ for $\mathrm{S} 4$ and $7.5 \mathrm{~h}$ for $\mathrm{D} 5$; Fig. 1), implying post-release mortality of those individuals. In all of these instances, the constant depth readings were consistent with maximum water depths in the PSAT detachment locations. Vertical movement profiles prior to mortality showed all 3 sharks diving to around $40 \mathrm{~m}$ immediately following release (Fig. 1). S4 and S7 remained in the middle to upper portion of the water column before a sudden descent to the bottom (presumably upon death), while D5 gradually descended to the seafloor. Overall, the short-term post-release mortality rates for sharks longline-hooked and released (alive and in good condition) for the purposes of this study were $25.0 \%$ for C. plumbeus and $12.5 \%$ for C. obscurus. Notably, there was no apparent correlation of these implied deaths with longer time on the hook compared with the range for surviving sharks (1:41, 4:42 and 11:02 compared to 1:33-18:12; Table 1).

\section{Horizontal movements}

All 16 PSATs transmitted pop-up locations, with all transmitting usable archived data to ARGOS satellites and 6 ultimately physically recovered (Table 1).

Table 1. Summary of biological characteristics, time on hook, tagging and tracking data for 8 Carcharhinus plumbeus (S1-S8) and 8 C. obscurus (D1-D8). Date detached: date depth changes no longer occurred; track length: length of most probable track; movement rate: daily movement rate based on most probable track. Linear distance is defined as the shortest possible distance from point of release to pop-up location

\begin{tabular}{|c|c|c|c|c|c|c|c|c|c|c|c|c|c|}
\hline ID & Sex & $\begin{array}{l}\text { Total } \\
\text { length } \\
(\mathrm{cm})\end{array}$ & $\begin{array}{c}\text { Time on } \\
\text { hook } \\
\text { (h:min) }\end{array}$ & $\begin{array}{c}\text { Date } \\
\text { tagged } \\
\text { (dd/mm/yy) }\end{array}$ & \multicolumn{2}{|c|}{ Tagging location } & $\begin{array}{c}\text { Date tag } \\
\text { detached } \\
\text { (dd/mm/yy) }\end{array}$ & \multicolumn{2}{|c|}{ Pop-up location } & $\begin{array}{l}\text { Days } \\
\text { tracked }\end{array}$ & $\begin{array}{l}\text { Linear } \\
\text { distance } \\
(\mathrm{km})\end{array}$ & $\begin{array}{l}\text { Track } \\
\text { length } \\
(\mathrm{km})\end{array}$ & $\begin{array}{c}\text { Movement } \\
\text { rate } \\
\left(\mathrm{km} \mathrm{d}^{-1}\right)\end{array}$ \\
\hline $\mathrm{S} 2$ & $\mathrm{~F}$ & 215 & $6: 49$ & $7 / 04 / 13$ & 30.000 & 153.336 & $11 / 04 / 13$ & 31.025 & 153.853 & 3.9 & 124.2 & 144.9 & 36.9 \\
\hline $\mathrm{S}^{\mathrm{a}}$ & $\mathrm{F}$ & 223 & $3: 30$ & $7 / 04 / 13$ & 30.003 & 153.335 & $28 / 04 / 13$ & 27.062 & 154.322 & 21.5 & 340.9 & 725.3 & 33.7 \\
\hline $\mathrm{S} 4^{\mathrm{b}}$ & M & 203 & $4: 42$ & $7 / 04 / 13$ & 30.009 & 153.333 & $11 / 04 / 13$ & 30.008 & 153.333 & 0.2 & 1.5 & - & - \\
\hline$S 7^{a, b}$ & $\mathrm{~F}$ & 214 & 11:01 & $8 / 04 / 13$ & 30.060 & 153.342 & $12 / 04 / 13$ & 29.964 & 153.388 & 0.1 & 11.5 & - & - \\
\hline S8 & $\mathrm{F}$ & 205 & $14: 54$ & 8/04/13 & 30.074 & 153.336 & $10 / 06 / 13$ & 30.009 & 153.450 & 59.7 & 13.1 & 968.5 & 16.2 \\
\hline $\mathrm{D} 1^{\mathrm{a}}$ & $\mathrm{F}$ & 310 & $18: 12$ & 7/04/13 & 30.098 & 153.329 & $8 / 05 / 13$ & 25.315 & 154.300 & 30.4 & 540.4 & 678.5 & 22.4 \\
\hline D2 & $\mathrm{M}$ & 209 & $4: 44$ & $10 / 04 / 13$ & 30.163 & 153.353 & $12 / 04 / 13$ & 31.626 & 153.775 & 1.9 & 167.6 & 170.2 & 89.1 \\
\hline D3 & $\mathrm{F}$ & 352 & $5: 51$ & $14 / 04 / 13$ & 30.010 & 153.357 & $21 / 04 / 13$ & 28.284 & 154.286 & 7.7 & 212.1 & 278.1 & 35.9 \\
\hline $\mathrm{D} 4^{\mathrm{a}}$ & $\mathrm{M}$ & 241 & $7: 12$ & 8/05/13 & 30.588 & 153.219 & $25 / 05 / 13$ & 25.226 & 154.316 & 16.5 & 605.9 & 695.0 & 42.2 \\
\hline $\mathrm{D} 5^{\mathrm{a}, \mathrm{b}}$ & $\mathrm{F}$ & 354 & $1: 41$ & $14 / 05 / 13$ & 30.009 & 153.366 & $19 / 05 / 13$ & 29.926 & 153.455 & 0.3 & 12.6 & - & - \\
\hline
\end{tabular}



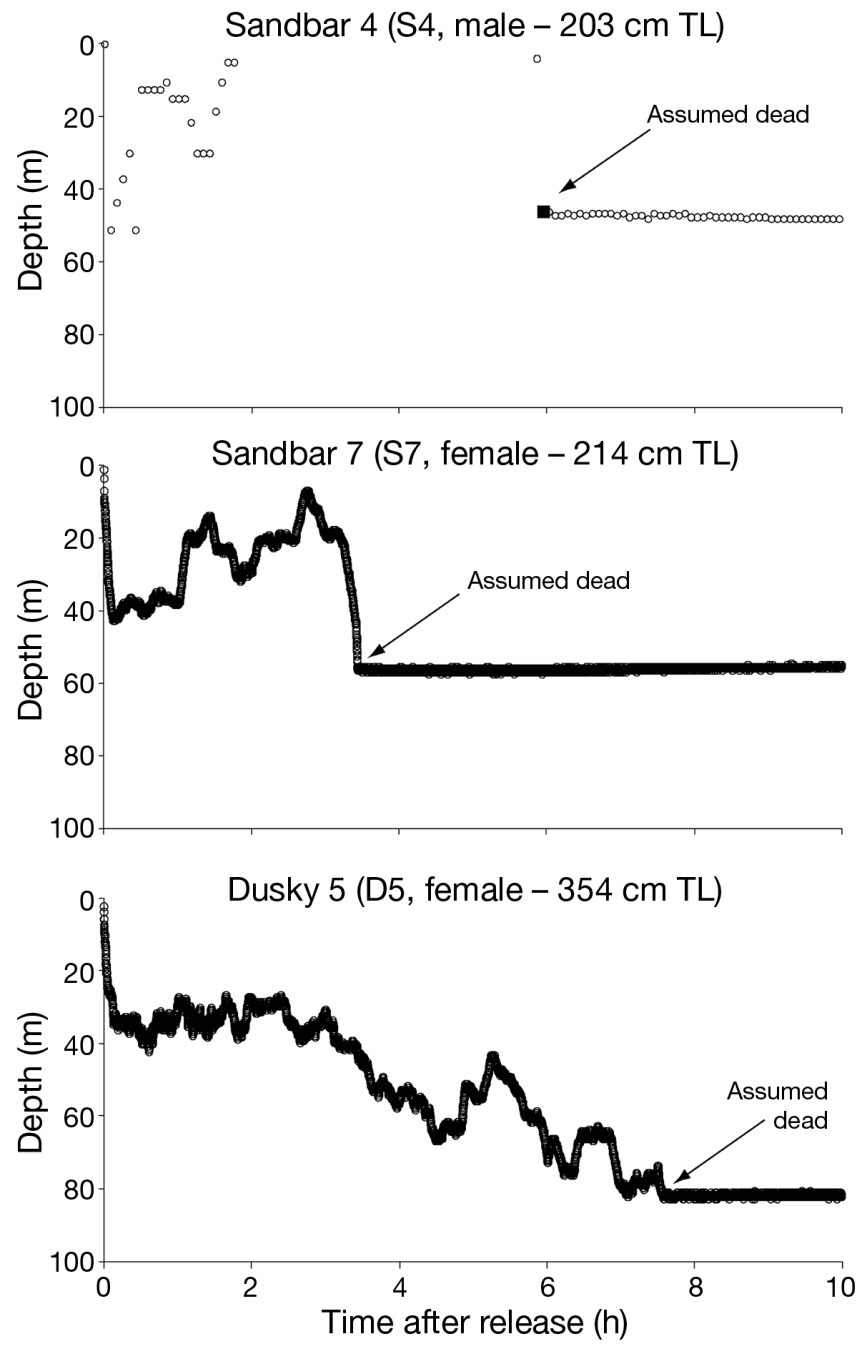

Fig. 1. Depth profiles for 2 tagged Carcharhinus plumbeus (S4, S7) and 1 C. obscurus (D5) presumed to have died within $8 \mathrm{~h}$ of release following capture and onboard tag attachment. Profiles produced using time-series data with 5 min intervals

During the first $24 \mathrm{~h}$ following release, almost all surviving sharks swam generally east to oceanic waters beyond the edge of the continental shelf, between $\sim 55 \mathrm{~km}$ and $\sim 180 \mathrm{~km}$ from the coast, before moving either generally south or north in longshore directions (Figs. 2 \& 3). Deployment times for each of the PSATs fell well short of the programmed $100 \mathrm{~d}$ (Table 1). Excluding the 3 presumed initial mortalities, PSAT detachment from 6 sharks (S1, S2, S5, S6, D2 and D8) occurred after $<1$ wk, with pop-up locations (i.e. linear displacements [LDs]) between 92 and $220 \mathrm{~km}$ away and all generally south from tag deployment locations. PSATs detached from a further 6 sharks (S3, D1, D3, D4, D6 and D7) after a week to a month, with LDs between 212 and $606 \mathrm{~km}$ away and all generally north from tag deployment. PSAT detachment for the remaining shark (S8) occurred after $60 \mathrm{~d}$, at a position close to initial tag deployment (13 km LD). During that time, however, the shark had travelled east, and then approximately south, for $\sim 350 \mathrm{~km}$ before returning (Fig. 2) and apparently dying (Fig. 4).

Mean $\mathrm{LD} \pm \mathrm{SE}$ was $121.4 \pm 42.1 \mathrm{~km}$ for $C$. plumbeus and $315.8 \pm 78.0 \mathrm{~km}$ for C. obscurus (Table 1). Filtering and analysis of PSAT geolocation estimates were undertaken for 13 of the 16 sharks (6 C. plumbeus and 7 C. obscurus). All C. plumbeus headed in easterly and then generally southerly directions within the first $5 \mathrm{~d}$ following release, although both S3 $(22 \mathrm{~d}$ deployment) and S8 turned north after around 5 and $30 \mathrm{~d}$, respectively, and swam in net northerly directions for $\sim 430 \mathrm{~km}$ and $\sim 350 \mathrm{~km}$, respectively (Fig. 2). Notably, the remaining $3 \mathrm{C}$. plumbeus were not tracked for longer than $6 \mathrm{~d}$. Five of the $7 \mathrm{C}$. obscurus headed in northerly directions (Fig. 3). The lengths of the most probable tracks ranged from 108.5 to $968.5 \mathrm{~km}$ for C. plumbeus and 151.3 to $821.6 \mathrm{~km}$ for C. obscurus (Table 1). Mean ( $\pm \mathrm{SE}$ ) distances swum according to these tracks were $409.7 \pm 124.6 \mathrm{~km}$ and $468.9 \pm 96.4 \mathrm{~km}$ for each species, respectively. For both species, distances travelled in the first $24 \mathrm{~h}$ following release were consistently further than subsequent days, representing a possible behavioural response to capture. Mean $( \pm \mathrm{SE})$ movement rates were $37.9 \pm 5.6 \mathrm{~km} \mathrm{~d}^{-1}$ (range of 16.2 to $56.6 \mathrm{~km} \mathrm{~d}^{-1}$ ) for $C$. plumbeus and $45.6 \pm 8.7 \mathrm{~km} \mathrm{~d}^{-1}$ (range of 22.4 to $89.1 \mathrm{~km} \mathrm{~d}^{-1}$ ) for C. obscurus (Table 1). However, excluding the first day of movement from calculations, mean movement rates were relatively shorter at 25.5 $\pm 4.5 \mathrm{~km} \mathrm{~d}^{-1}$ (9.7 to $42.2 \mathrm{~km} \mathrm{~d}^{-1}$ ) for C. plumbeus and $39.5 \pm 6.4 \mathrm{~km} \mathrm{~d}^{-1}$ (20.9 to $69.4 \mathrm{~km} \mathrm{~d}^{-1}$ ) for C. obscurus.

A total of 3984 detections from 4 C. plumbeus (S1, S2, S3 and S5) and 6 C. obscurus (D1, D2, D3, D4, D6 and D8) were recorded by 28 acoustic receivers between April 2013 and August 2014 (Table 2), providing evidence of long-term survival and some support for movements estimated via PSAT (Figs. 2 \& 3). All of those acoustic receivers were between 10 and $28 \mathrm{~km}$ from shore. Most C. plumbeus detections occurred within $30 \mathrm{~km}$ of the release location, including 2 sharks ( $\mathrm{S} 1$ and $\mathrm{S} 3$ ) that returned after $>12 \mathrm{mo}$, following final PSAT positional estimates at $220 \mathrm{~km}$ south and $341 \mathrm{~km}$ north of release, respectively (Table 2, Fig. 2). The greatest movements of $C$. obscurus detected by the acoustic array were to waters off Brisbane to the north (D1; $310 \mathrm{~km}$ from release) and Sydney to the south (D6 and D8; $\sim 515 \mathrm{~km}$ from release). Only 1 shark (D4) was 

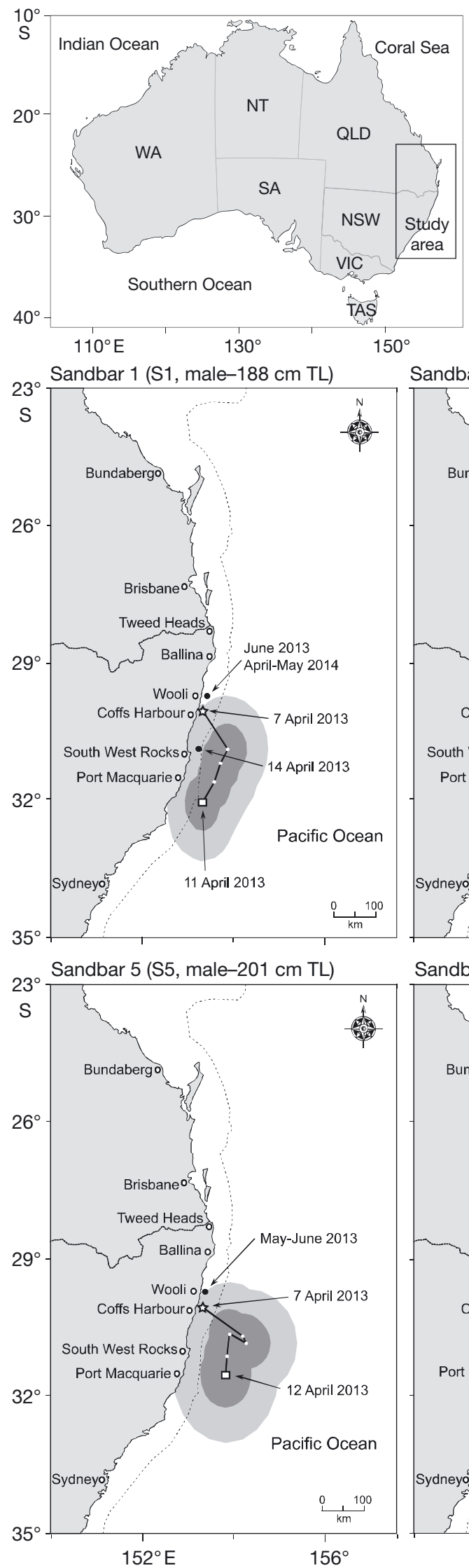

Fig. 2. Map of Australia (including larger states and territories) showing the extent of the study area and general location of Carcharhinus plumbeus shark capture and tagging (star) and last known location (square). Most probable tracks (track way-points = days) of $C$. plumbeus generated via Kalman filtering of PSAT light-level readings. Broken line: edge of continental shelf; light grey shading: 95\% confidence intervals $(\mathrm{CI})$; dark grey shading: $50 \% \mathrm{CI}_{\text {; }}$ : detections by acoustic receivers

Sandbar 2 (S2, female-215 cm TL)

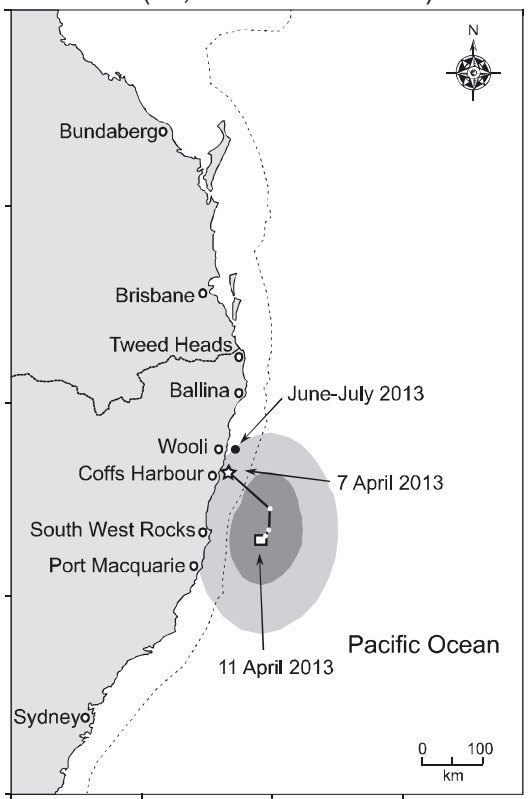

Sandbar 6 (S6, male-184 cm TL)

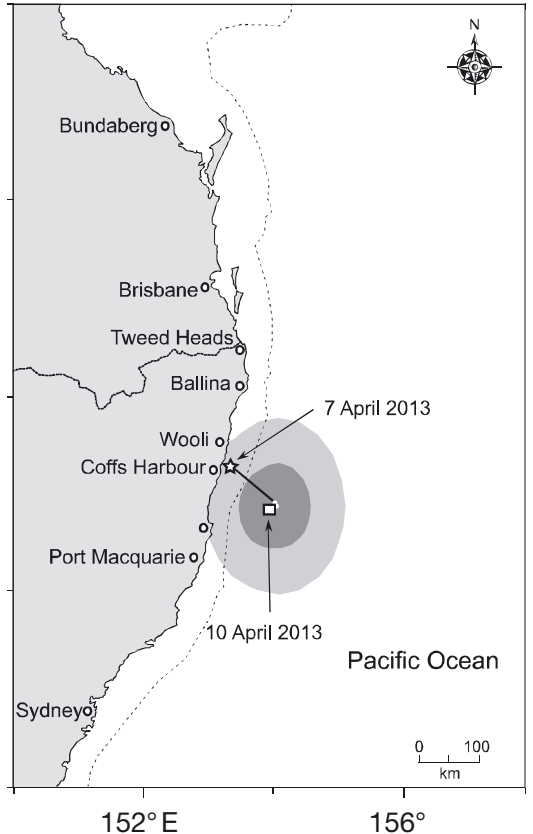

Sandbar 3 (S3, female-223 cm TL)

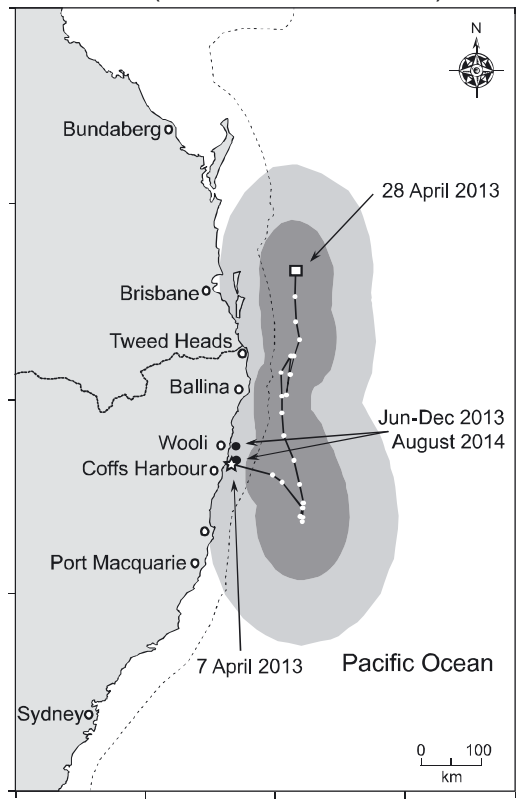

Sandbar 8 (S8, female-205 cm TL)

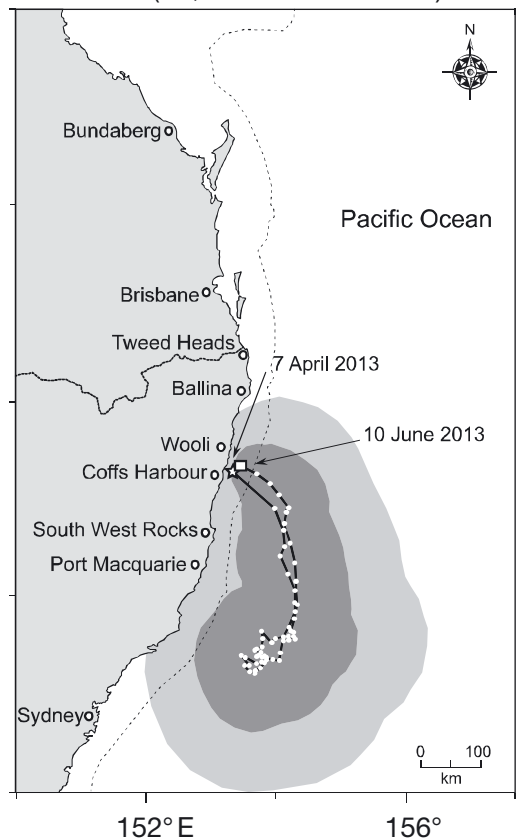



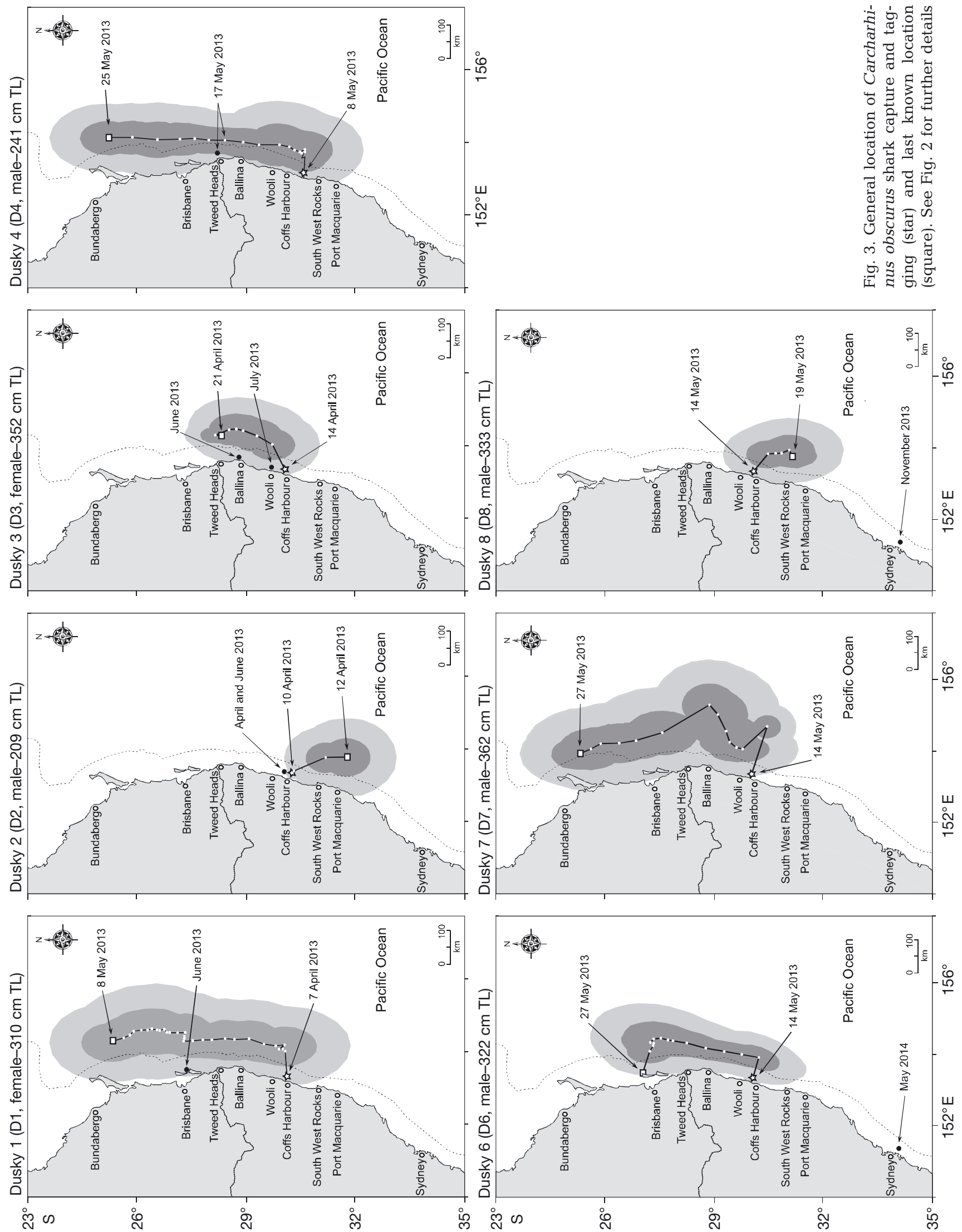
detected whilst the PSAT tag was still attached, by a listening station attached to a Fish Aggregating Device (FAD) located $15 \mathrm{~km}$ off the coast from Tweed Heads, $17 \mathrm{~d}$ after release (Table 2, Fig. 3). This detection occurred within $50 \mathrm{~km}$ of the most probable track and $50 \%$ confidence intervals indicated by PSAT geolocation estimates. Of the 13 surviving tagged sharks, only 2 C. plumbeus (S6 and S8) and 1 C. obscurus (D7) remained undetected by the acoustic receivers over the first 18 mo following release.

\section{Depth and temperature associations}

Both species spent the majority of time in the upper $100 \mathrm{~m}$ of the water column. Collectively, tagged $C$. plumbeus spent $8.7 \%$ of their time at $<20 \mathrm{~m}, 31.6 \%$ at $20-40 \mathrm{~m}, 22.2 \%$ at $40-60 \mathrm{~m}, 10.8 \%$ at $60-80 \mathrm{~m}$, $14.1 \%$ at $80-100 \mathrm{~m}$ and $12.7 \%$ in waters $>100 \mathrm{~m}$ deep. In contrast, tagged C. obscurus spent time more evenly among those depths, at 15.6, 17.4, 21.1, 18.6, 11.3 and $16.0 \%$, respectively. Excluding times of release and PSAT detachment, depths recorded by PSATs ranged from 0 to $287 \mathrm{~m}$ for C. plumbeus and 0 to $498 \mathrm{~m}$ for $C$. obscurus (Table 3 ), with only $2 C$. plumbeus visiting the surface over the duration of the study (Fig. 4). In contrast, 6 of the 7 surviving $C$. obscurus visited the surface, with 4 of these (D1, D3, D4 and D6) surfacing on at least $78 \%$ of days tracked.

Individually, mean depth and time spent in the mixed layer (ML) varied considerably (Table 3). S8 was the only $C$. plumbeus with a mean depth \pm SE of

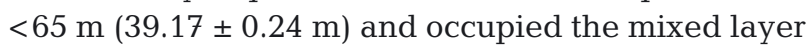
for the highest percentage of tracked time $(72 \%)$ compared with other C. plumbeus (16 to 55\%). For their respective species, S6 and D8 had the highest mean depth $(86.2 \pm 1.1$ and $107.0 \pm 1.4 \mathrm{~m}$, respectively) and lowest percentage of time spent in the mixed layer (16 and $22 \%$, respectively). Collectively, C. plumbeus occupied waters below the ML $63 \%$ of the time, whereas C. obscurus were deeper than the ML only $42 \%$ of the time. Despite both species spending most time in the upper $100 \mathrm{~m}$ of the water column $(84.0 \%$ for C. plumbeus and $87.3 \%$ for $C$. obscurus), some individuals undertook dives considerably deeper than other conspecifics, and although the duration of these dives were always $<5 \mathrm{~min}$, some individuals (i.e. D8) spent up to $12 \mathrm{~h}$ at depths below $150 \mathrm{~m}$. S3 (maximum depth $302.5 \mathrm{~m}$ ) was the only $C$. plumbeus to exceed $250 \mathrm{~m}$ and did so on 2 occasions (Fig. 4). Similarly, D3 (maximum $498.0 \mathrm{~m}$ ) and D6 (maximum $336.5 \mathrm{~m}$ ) each made 2 dives to $>300 \mathrm{~m}$ and were the only C. obscurus to exceed this depth.
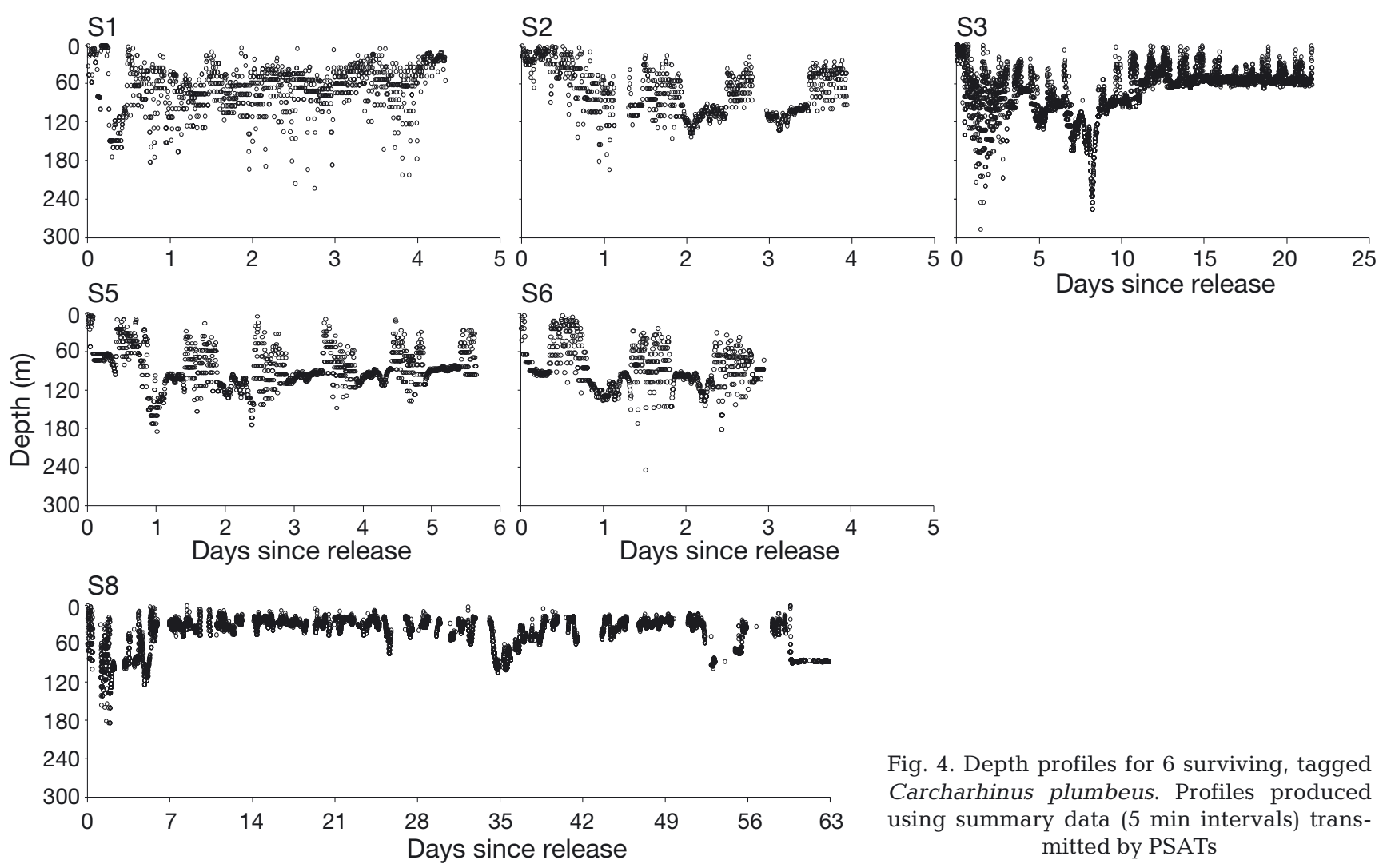

Fig. 4. Depth profiles for 6 surviving, tagged Carcharhinus plumbeus. Profiles produced using summary data (5 min intervals) transmitted by PSATs 
Table 2. Listening station (receiver) detections of 4 Carcharhinus plumbeus and 6 C. obscurus via acoustic transmissions during the first 18 mo post-release. Receiver locations are north to south along the eastern seaboard of Australia (see Figs. 2 \& 3)

\begin{tabular}{|c|c|c|c|c|c|}
\hline $\begin{array}{r}\text { Receiver } \\
\text { location }\end{array}$ & $\begin{array}{l}\text { Lat. } \\
\left({ }^{\circ} \mathrm{S}\right)\end{array}$ & $\begin{array}{l}\text { Long. } \\
\left({ }^{\circ} \mathrm{E}\right)\end{array}$ & $\begin{array}{l}\text { Distance from } \\
\text { mainland } \\
(\mathrm{km})\end{array}$ & $\begin{array}{c}\text { Shark } \\
\text { ID }\end{array}$ & $\begin{array}{c}\text { No. of } \\
\text { detections }\end{array}$ \\
\hline \multirow[t]{2}{*}{ Brisbane } & 27.312 & 153.460 & 28 & D1 & 1 \\
\hline & 27.346 & 153.485 & 27 & D1 & 1 \\
\hline Tweed Heads & 28.162 & 153.683 & 12 & D4 & 12 \\
\hline Ballina & 28.868 & 153.694 & 9 & D3 & 1 \\
\hline \multirow[t]{25}{*}{ Wooli } & 29.929 & 153.300 & 3 & S3 & 12 \\
\hline & 29.928 & 153.308 & 3.7 & S3 & 48 \\
\hline & 29.929 & 153.316 & 4.4 & $\mathrm{~S} 1$ & 56 \\
\hline & & & & S3 & 43 \\
\hline & & & & $\mathrm{S} 2$ & 2 \\
\hline & 29.929 & 153.324 & 5.2 & $\mathrm{~S} 1$ & 112 \\
\hline & & & & S3 & 243 \\
\hline & & & & $\mathrm{S} 2$ & 21 \\
\hline & 29.929 & 153.333 & 6 & D3 & 1 \\
\hline & & & & S3 & 21 \\
\hline & 29.929 & 153.341 & 6.8 & D3 & 127 \\
\hline & & & & $\mathrm{S} 1$ & 16 \\
\hline & & & & S3 & 158 \\
\hline & 29.929 & 153.349 & 7.6 & D3 & 67 \\
\hline & & & & $\mathrm{S} 1$ & 9 \\
\hline & & & & S3 & 231 \\
\hline & 29.929 & 153.358 & 8.4 & S3 & 311 \\
\hline & 29.929 & 153.366 & 9.2 & S3 & 290 \\
\hline & 29.929 & 153.374 & 10 & S1 & 1 \\
\hline & & & & S3 & 121 \\
\hline & 29.929 & 153.382 & 10.8 & $\mathrm{~S} 1$ & 16 \\
\hline & & & & S3 & 309 \\
\hline & 29.929 & 153.399 & 12.3 & S3 & 129 \\
\hline & 29.878 & 153.435 & 15 & S3 & 42 \\
\hline & & & & S5 & 12 \\
\hline \multirow{2}{*}{$\begin{array}{l}\text { Nth Solitary } \\
\text { Island }\end{array}$} & 29.931 & 153.499 & 11.3 & S3 & 38 \\
\hline & 29.923 & 153.499 & 11.3 & S3 & 1138 \\
\hline $\begin{array}{l}\text { NW Solitary } \\
\text { Island }\end{array}$ & 30.019 & 153.500 & 5.2 & S3 & 2 \\
\hline \multirow{2}{*}{$\begin{array}{l}\text { Sth Solitary } \\
\text { Island }\end{array}$} & 30.203 & 153.503 & 7.8 & S3 & 332 \\
\hline & 30.202 & 153.266 & 7.6 & $\mathrm{~S} 3$ & 14 \\
\hline Coffs Harbour & 30.267 & 153.283 & 27.5 & D2 & 4 \\
\hline $\begin{array}{l}\text { South West } \\
\text { Rocks }\end{array}$ & 30.842 & 153.197 & 12 & $\mathrm{~S} 1$ & 10 \\
\hline \multirow[t]{4}{*}{ Sydney } & 33.948 & 151.375 & 10.2 & D8 & 2 \\
\hline & 33.952 & 151.382 & 10.9 & D8 & 2 \\
\hline & 33.980 & 151.427 & 14.3 & D6 & 11 \\
\hline & 33.984 & 151.434 & 15.3 & D6 & 6 \\
\hline
\end{tabular}

Patterns of vertical movement of C. plumbeus within mid-water depths $(>20 \mathrm{~m})$ generally coincided with periods of day and night and were generally consistent among individuals (Fig. 4), with deeper water generally occupied during daylight hours (Figs. 4 \& 5). During daylight, mean ( \pm SE) depth and temperature for $C$. plumbeus were $76.8 \pm 9.4 \mathrm{~m}$ and $21.4 \pm 0.1^{\circ} \mathrm{C}$, respectively, while at night, these val- ues were $63.4 \pm 5.2 \mathrm{~m}$ and $22.6 \pm 0.2^{\circ} \mathrm{C}$, respectively. Despite the apparent pattern, KS tests found no statistically significant diel differences for depth $(\mathrm{D}=$ 0.67, $\mathrm{p}=0.14$ ) and temperature $(\mathrm{D}=0.50, \mathrm{p}=0.47)$. With the exception of D1, there were no clear diel patterns of vertical movement apparent in depth and temperature plots for individual C. obscurus (Figs. 5 \& 6), although collectively they appear to occupy shallower water $(<40 \mathrm{~m}$ deep) proportionally more during the night than daylight (Fig. 5). During daylight, mean $( \pm \mathrm{SE})$ depth and temperature for $C$. obscurus were $70.9 \pm 9.1 \mathrm{~m}$ and $22.6 \pm 0.5^{\circ} \mathrm{C}$, respectively, while at night, these values were $67.7 \pm 7.7 \mathrm{~m}$ and $22.6 \pm 0.5^{\circ} \mathrm{C}$, respectively. However, as for $C$. plumbeus, KS tests found no statistically significant diel differences for depth $(\mathrm{D}=0.14, \mathrm{p}=1.00)$ and temperature $(\mathrm{D}=0.14, \mathrm{p}=1.00)$.

Depths and temperatures were closely related. Despite both species occupying a wide thermal range, a clear preference for a specific range was evident. Specifically, C. plumbeus spent $43.5 \%$ of their time in water temperatures between 22 and $24^{\circ} \mathrm{C}$, while C. obscurus spent $69.1 \%$ of their time in temperatures between 22 and $26^{\circ} \mathrm{C}$. Mean temperatures logged for C. plumbeus ranged from $20.8 \pm 0.1$ to 23.5 $\pm 0.1^{\circ} \mathrm{C}$ and for C. obscurus from $20.1 \pm 0.1$ to $24.2 \pm$ $<0.05^{\circ} \mathrm{C}$.

\section{DISCUSSION}

This work is the first study reporting the movement of Carcharhinus plumbeus and C. obscurus in waters off eastern Australia. It combines data from PSATs and internal acoustic tags associated with 8 sharks of each species, in an attempt to evaluate the survivorship and behaviour of sharks caught and released from demersal longlines. Despite the problems associated with premature tag releases across both species, the large-scale horizontal movements potentially managed by multiple jurisdictions (NSW, Queensland and Commonwealth fisheries) indicates that a collective management approach would clearly be appropriate for these species and the fishing methods used to catch them.

\section{Pop-up satellite tag retention}

Premature detachment of PSATs, as was the case for $75 \%$ of the tag deployments in this study, has been common in studies employing this technology (Musyl et al. 2011). Reasons for the premature re- 
Table 3. Mean $( \pm \mathrm{SE})$ depth $(\mathrm{m})$ and water temperatures $\left({ }^{\circ} \mathrm{C}\right)$; depth ranges; and percentage of time spent in mixed layer (ML) recorded for each Carcharhinus plumbeus (S1-S8) and C. obscurus (D1-D8). Maximum depths displayed were based on archived data ( 3 s intervals) where PSATs were recovered

\begin{tabular}{|c|c|c|c|c|c|c|c|}
\hline \multirow{2}{*}{$\begin{array}{l}\text { Shark } \\
\text { ID }\end{array}$} & \multicolumn{3}{|c|}{$\longrightarrow$ Depth } & \multicolumn{3}{|c|}{ Temperature -} & \multirow{2}{*}{$\begin{array}{l}\text { ML } \\
(\%)\end{array}$} \\
\hline & Min-Max & Mean & $\pm \mathrm{SE}$ & Min-Max & Mean & $\pm \mathrm{SE}$ & \\
\hline S1 & $0.5-223.0$ & 65.33 & 1.06 & $15.1-25.6$ & 23.48 & 0.06 & 54.7 \\
\hline $\mathrm{S} 2$ & $1.0-194.0$ & 73.30 & 1.12 & $17.8-25.5$ & 21.91 & 0.07 & 45.6 \\
\hline $\mathrm{S} 3_{\mathrm{a}}$ & $0-302.5$ & 71.01 & 0.46 & $14.3-25.9$ & 22.42 & 0.03 & 24.8 \\
\hline $\mathrm{S} 4_{\mathrm{b}}$ & $4.0-51.0$ & 22.57 & 3.11 & $20.8-24.2$ & 22.57 & 0.27 & 33.3 \\
\hline S5 & $1.5-183.5$ & 85.46 & 0.73 & $16.2-25.5$ & 20.79 & 0.05 & 19.0 \\
\hline S6 & $2.5-243.5$ & 86.17 & 1.11 & $14.1-25.3$ & 21.00 & 0.07 & 16.2 \\
\hline$S 7^{\mathrm{a}, \mathrm{b}}$ & $8.0-47.5$ & 27.50 & 1.60 & $21.2-23.1$ & 23.05 & 0.12 & 28.9 \\
\hline S8 & 0-183.0 & 39.17 & 0.25 & $16.4-25.3$ & 22.46 & 0.01 & 71.7 \\
\hline $\mathrm{D} 1^{\mathrm{a}}$ & $0-267.5$ & 47.66 & 0.30 & $15.2-26.1$ & 23.32 & 0.02 & 51.0 \\
\hline D2 & $5.0-168.5$ & 75.17 & 1.42 & $15.2-25.7$ & 22.23 & 0.12 & 41.9 \\
\hline D3 & $0-498.0$ & 52.89 & 1.17 & $10.2-25.9$ & 24.17 & 0.04 & 72.9 \\
\hline $\mathrm{D} 4^{\mathrm{a}}$ & $0-241.5$ & 55.93 & 0.41 & $15.0-24.8$ & 22.57 & 0.03 & 51.9 \\
\hline $\mathrm{D} 5^{\mathrm{a}, \mathrm{b}}$ & $28.0-81.5$ & 50.01 & 1.79 & $20.1-23.8$ & 20.10 & 0.13 & 97.7 \\
\hline $\mathrm{D}^{\mathrm{a}}$ & $0-336.5$ & 82.14 & 3.30 & $11.7-24.4$ & 22.51 & 0.34 & 48.5 \\
\hline D7 & $0-220.5$ & 63.67 & 0.67 & $17.5-24.6$ & 22.74 & 0.03 & 74.5 \\
\hline D8 & $0-281.0$ & 106.99 & 1.41 & $14.5-24.4$ & 20.36 & 0.06 & 21.9 \\
\hline
\end{tabular}

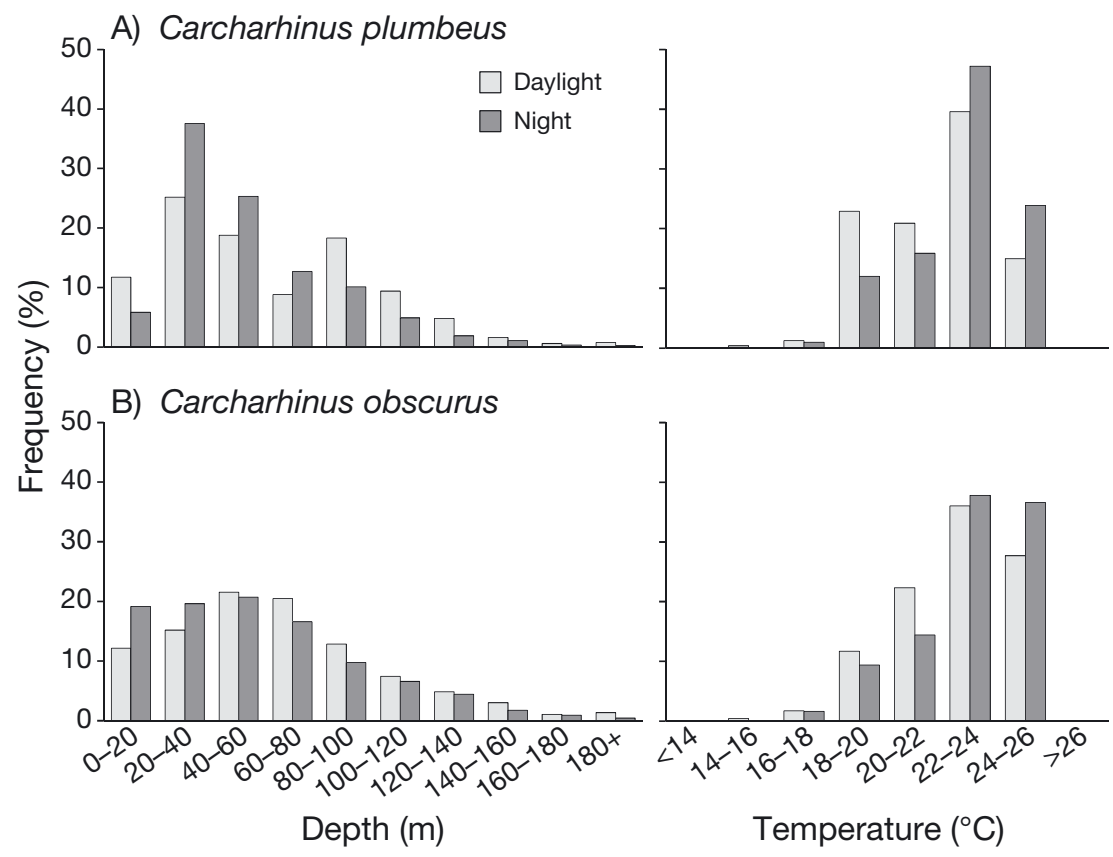

Fig. 5. Percentage of time spent by (A) Carcharhinus plumbeus and (B) $C$. obscurus at various depths and temperatures during the day and night mature detachment was the failure of the tag anchor (Domeier umbrella darts). Attempts at forcible removal via self-abrasion using substratum or bites by conspecifics have been observed in some carcharhinids (Hammerschlag et al. 2011). Although these types of behaviours may have contributed to detachment in our research, PSATs have been successfully attached and retained until pre-programmed pop-up dates for both $C$. plumbeus (Conrath \& Musick 2008) and C. obscurus (Rogers et al. 2013, Hoffmayer et al. 2014) in other studies.

\section{Post-release mortality}

This study produced 3 clear cases of short-term post-release mortality of tagged sharks: 2 C. plumbeus and 1 C. obscurus. These fatalities were recorded despite the deployment of PSATs only on sharks whose condition indexes indicated that they were healthy and likely to survive to provide useful data on movement, with moribund sharks and those with low condition index scores (and likely to die) specifically rejected. No association between time on hook and postrelease mortality was evident. One additional, longer-term mortality of a C. plumbeus following $60 \mathrm{~d}$ of PSAT deployment was indicated by the tracking data submitted, although there is no evidence that this death was related to capture and tagging as part of this study. Evidence of ongoing survival was confirmed for 10 of the 12 remaining sharks after PSAT detachment by detections by acoustic receivers, highlighting the benefits of dual acoustic and archival satellite tagging methodology.

\section{Horizontal movements}

lease of many of the PSATs in this study are unclear. However, the recovery of 1 PSAT to which the tether and dart remained attached showed damage consistent with forcible removal from the dorsal musculature: this suggests that the most likely reason for pre-
Tracks shorter than maximum geolocation error generally offer little reliable information on the movement of individual sharks. However, the short 

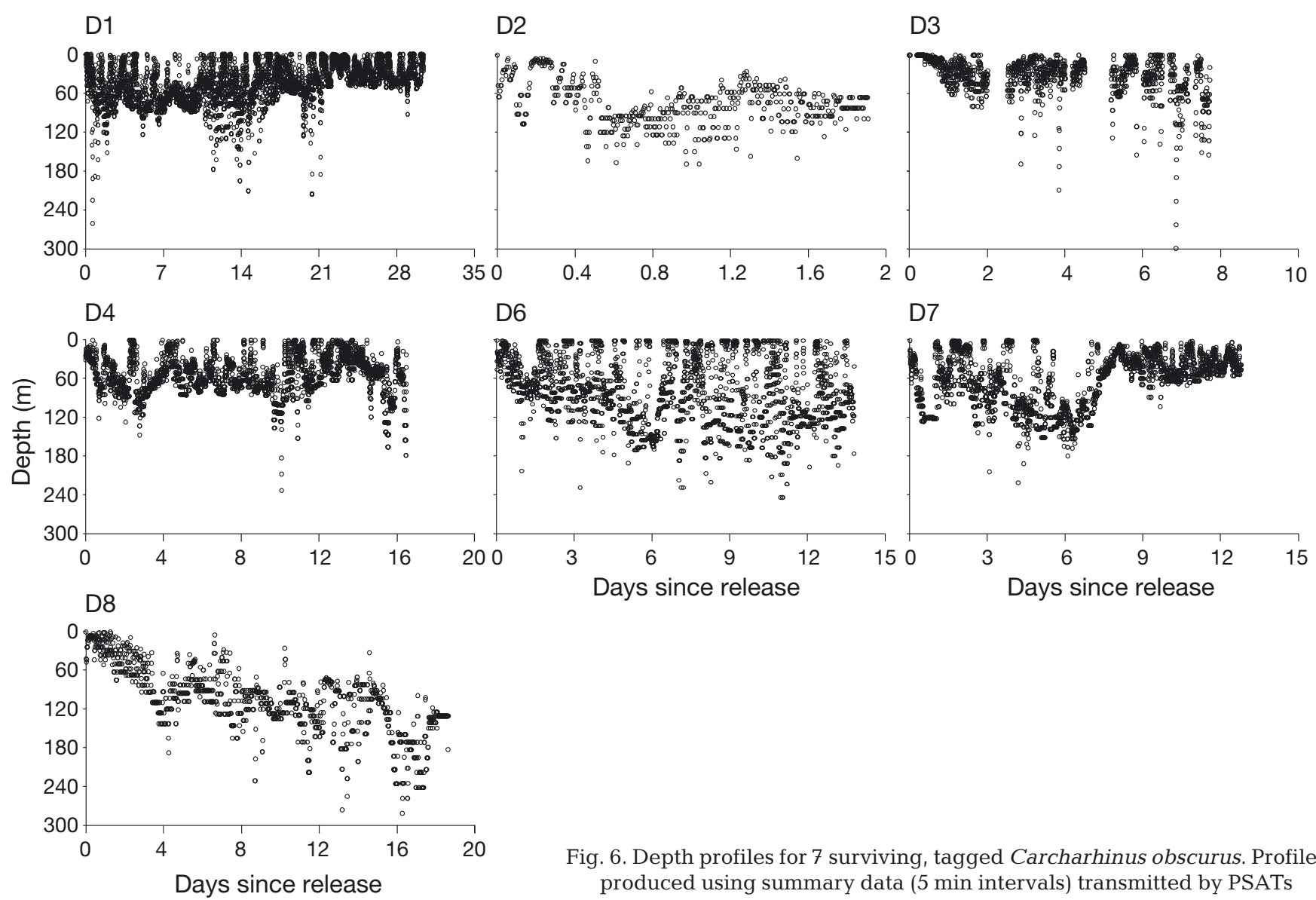

Fig. 6. Depth profiles for 7 surviving, tagged Carcharhinus obscurus. Profiles produced using summary data (5 min intervals) transmitted by PSATs

tracks were included here to highlight the limitations of light-based geolocation, demonstrate a consistent pattern of movement away from the coast immediately after release and help establish a possible affinity for continental-shelf-edge waters. Movement away from the coast immediately after release was indicated in the most probable tracks of all 13 surviving sharks and is likely to be a behavioural reaction to capture, as has previously been found for $C$. plumbeus (Rechisky \& Wetherbee 2003).

For both species, the most probable tracks estimated via PSATs followed, or remained in relatively close proximity to, the continental slope, with most pop-up locations within $50 \mathrm{~km}$ of the shelf edge, irrespective of latitudinal displacement. Utilisation of continental slope and adjacent oceanic waters could indicate a preferred habitat for both species, as has been previously reported elsewhere. Using traditional tag-recapture and catch-reporting methods, adult $C$. obscurus have been reported in outer-shelf waters off eastern South Africa (Hussey et al. 2009) and the Gulf of Mexico (Baum \& Myers 2004). More recently, studies using PSATs have shown continental-slope waters to be important habitat for this spe- cies off southern Australia (Rogers et al. 2013) and in the Gulf of Mexico (Hoffmayer et al. 2014). Similar affinity for this habitat by C. plumbeus has been previously observed off the coast of Brazil (Hazin et al. 2007). Continental-shelf edges are known to attract large predators, probably due to a complex and productive habitat likely to support abundant prey, including teleosts, cephalopods and elasmobranchs, which are the primary food source of adult and large juvenile C. plumbeus and C. obscurus (Simpfendorfer et al. 2001, Baum \& Myers 2004, McElroy et al. 2006).

While estimates of longitude generated from PSAT light-level readings are considered to be accurate and robust (Teo et al. 2004), latitudinal estimates are considered far less accurate: consequently, several studies have opted to use only longitude to yield information on movements (e.g. Domeier \& NasbyLucas 2008, Rogers et al. 2013). However, to evaluate movements and migrations of C. plumbeus and C. obscurus along the north-south gradient of the east coast of Australia, generating estimates of latitudinal movements via PSAT data was an essential focus of this study. Track lengths of $>500 \mathrm{~km}$ in con- 
sistent latitudinal directions were estimated for both species and verified by acoustic receiver detections, providing valuable and reliable broad-scale spatial information despite inherent inaccuracies in the methodology.

Using conventional tag-recapture techniques that provide only a starting point and final destination, Grubbs et al. (2007) reported LDs for C. plumbeus of up to $2800 \mathrm{~km}$ over almost 6 yr. Using PSATs, Conrath \& Musick (2008) recorded LDs from tag deployment to pop-up of 236 to $469 \mathrm{~km}$ for C. plumbeus over 121 to $172 \mathrm{~d}$, compared with the maximum LD of $341 \mathrm{~km}$ in only $22 \mathrm{~d}$ recorded for this species in this study. However, these data ignore the movement patterns in the intervening periods and so are likely to result in considerable underestimates of horizontal movements and migrations, with potential error escalating substantially with an increase in intervening periods. This is particularly well demonstrated here by a tagged $C$. plumbeus that yielded a LD of only $13 \mathrm{~km}$ after almost $60 \mathrm{~d}$ of tracking, while the most probable track length was estimated at $969 \mathrm{~km}$ and involved a return trip to a location $\sim 350 \mathrm{~km}$ south of release. The most direct large-scale movement of C. obscurus tracked in this study was $695 \mathrm{~km}$ to a pop-up location $606 \mathrm{~km}$ north of release, over $\sim 16 \mathrm{~d}$. This is generally comparable to large-scale migrations of $>2700 \mathrm{~km}$ reported by both Hoffmayer et al. (2014) (>90 d) and Rogers et al. (2013) (>182 d). Popup locations well north of the NSW/QLD border for both species confirm that their east-coast populations do indeed utilise multi-jurisdictional waters, and collaborative management of stocks is required.

Based on most probable tracks, movement rates estimated for C. plumbeus (16 to $57 \mathrm{~km} \mathrm{~d}^{-1}$ ) in this study were generally greater than the maximum speed of $22 \mathrm{~km} \mathrm{~d}^{-1}$ determined in a conventional tagging study (Kohler et al. 1998) and similar to rates of 27 to $60 \mathrm{~km} \mathrm{~d}^{-1}$ reported using acoustic telemetry (Rechisky \& Wetherbee 2003), both collected in waters off south-eastern USA. In contrast, movement rates estimated for $C$. obscurus ranged from 22 to $89 \mathrm{~km} \mathrm{~d}^{-1}$, which is far greater than rates reported in other studies done in waters in the Gulf of Mexico (9 to $31 \mathrm{~km} \mathrm{~d}^{-1}$; Hoffmayer et al. 2014), off South Africa (8 to $32 \mathrm{~km} \mathrm{~d}^{-1}$; Hussey et al. 2009), off south-eastern USA (41 km d ${ }^{-1}$; Kohler et al. 1998) and off southern Australia (9 to $15 \mathrm{~km} \mathrm{~d}^{-1}$; Rogers et al. 2013). The relatively higher mean rates of movement estimated in the present study are partially due to inclusion of data for the first $24 \mathrm{~h}$ following release, which in the cases of all tagged sharks was characterised by greater rates of movement than subsequent days.
While not quantified in the present study, this difference could be a short-term behavioural response to capture.

Site fidelity was difficult to assess given the short duration of PSAT attachment, although potential areas of philopatry were nevertheless identified. All 8 C. plumbeus were caught on the same day within $9 \mathrm{~km}$ of one another, with one returning 2 mo later to within $13 \mathrm{~km}$ of its capture location after swimming $\sim 350 \mathrm{~km}$ south. Further, over an 18 mo period after detachment of their PSATs, acoustic listening stations not far (within $10 \mathrm{~km}$ ) from the capture area made multiple, and in some cases repeated, detections of 4 other ( 2 males and 2 females) tagged C. plumbeus. Areas repeatedly visited by a species, as in the case here, may signify important ecological habitats and regions (Hueter et al. 2005). Large aggregations of adult $C$. plumbeus are usually associated with males during migrations (Compagno 1984), and site fidelity for the species generally relates to female nursery grounds (Portnoy et al. 2010). Because the sex ratios of PSAT-tagged C. plumbeus in this study were equal, and all individuals were fully mature, the possible site fidelity could be related to feeding or mating, although very few pregnant females were caught during the sampling period (Broadhurst et al. 2014, Butcher et al. 2015).

There was less evidence for philopatry in C. obscurus, with only 2 (male and female) of the 7 sharks returning to the general area in which they were tagged to be detected by acoustic receivers months after last being tracked to $>200 \mathrm{~km}$ either north or south by PSATs. A further possible area of site fidelity for C. obscurus could be inferred by the PSAT pop-up locations of 3 large sharks in a relatively small area off the coast of QLD between Fraser Island and the Recorder Tablemount. Undersea features such as seamounts feature similar complexity and productivity to continental-shelf edges, supporting a diversity of possible prey species (Hoffmayer et al. 2014). Given the pop-up of 3 PSATs within this area, and the well-reported incidences of antagonistic behaviour between sharks during mating and feeding (e.g. Pratt \& Carrier 2001), it is possible that behaviour associated with feeding or mating aggregations in the area was responsible for dislodging the tag anchors.

\section{Depth and temperature associations}

Both species displayed apparent preferences for depths in the upper $100 \mathrm{~m}$ of the water column and 
temperatures from 22 to $26^{\circ} \mathrm{C}$, although tolerances for both depth and temperature were broader. Similarly, thermal tolerances recorded in this study extended to $14.1^{\circ} \mathrm{C}$ for C. plumbeus and $10.2^{\circ} \mathrm{C}$ for $C$. obscurus, although neither species was inclined to occupy waters above $26^{\circ} \mathrm{C}$ in more northern waters during the tracking period. Occasional extreme diving behaviour was apparent in both species, with maximum depths recorded in this study (303 $\mathrm{m}$ for $C$. plumbeus and $498 \mathrm{~m}$ for C. obscurus) generally similar to those recorded for C. plumbeus off the Hawaiian Islands (278 m; Papastamatiou et al. 2006) and for C. obscurus off southern Australia (355 m; Rogers et al. 2013) and in the Gulf of Mexico (573 m; Hoffmayer et al. 2014). However, despite evidence suggesting that all sharks in the present study spent a significant amount of the time tracked over deep waters near the continental slope, deep dives were infrequent and short in duration.

Diel patterns featuring shallower and more active, vertical movement during the day, alternating with deeper, more depth-constant behaviour in the night, were demonstrated for all tagged $C$. plumbeus but generally not for the majority of C. obscurus. Although Papastamatiou et al. (2006) reported comparable behaviour by C. plumbeus in an unpublished preliminary study comprising 1 shark, this is the first time diel movement patterns have been consistently observed for the species. Such behaviour could be related to C. plumbeus pursuing vertically migrating fish and squid prey to maximise time spent feeding (Campana et al. 2011, Queiroz et al. 2012), while adult C. obscurus may have a greater reliance on larger teleost and elasmobranch prey over squid (Rogers et al. 2013). While both species displayed a strong preference for utilising the upper $100 \mathrm{~m}$ of the water column, C. plumbeus spent considerably more time beneath the ML than C. obscurus. Similar to behaviours documented in a study of blue sharks Prionace glauca (Queiroz et al. 2012), their presence within and below the ML is most likely for maintenance of their optimal thermal range or in response to prey distribution and behaviour. Conrath \& Musick (2008) described seasonal differences in vertical niches, where depths inhabited by $C$. plumbeus ranged from 0 to $24 \mathrm{~m}$ in summer and extended far deeper for greater periods of time throughout winter. Although the general behaviour they described is somewhat consistent with the vertical behaviour of this species found in this study, examination of seasonality is beyond the scope of this study due to the temporally limited tag deployment periods.

\section{CONCLUSIONS}

Short-term tracking by PSAT in this study has contributed greatly to the biological knowledge available for effective management of commercially exploited stocks of Carcharhinus plumbeus and $C$. obscurus along the east coast of Australia. Findings have demonstrated that a multi-jurisdictional approach to management of both species between NSW, QLD and Commonwealth fisheries should be considered. Further studies of post-release mortality of sharks discarded after being hooked by commercial demersal longline gears, using survivorship tags, could be an economical and effective method for resolving the viability of enforced discarding via TACs and trip limits.

Acknowledgements. The project was administered by Fisheries NSW through the New South Wales Department of Primary Industries (NSW DPI). Project funding was provided by the Fisheries Research and Development Corporation (FRDC grant no. 2010/062) on behalf of the Australian Government and NSW DPI, and with the support of Southern Cross University (SCU) and the Integrated Marine Observing System (IMOS) Animal Tracking Facility. Ethics approval was granted by the NSW DPI (Ref. 12/19) and SCU (Ref. 13/09) Animal Care and Ethics Committees. This project would not have been possible without the dedicated support of our research team (especially Dr. Shane McGrath), Kevin Lay and the staff at Wildlife Computers, and the skippers and crews of the commercial fishing vessels 'Menrae' and 'Joanne Glenn'.

\section{LITERATURE CITED}

Baranes A, BenTuvia A (1978) Occurrence of the sandbar shark (Carcharhinus plumbeus) in the northern Red Sea. Israel J Zool 27:45-51

Baum JK, Myers RA (2004) Shifting baselines and the decline of pelagic sharks in the Gulf of Mexico. Ecol Lett $7: 135-145$

Baum JK, Myers RA, Kehler DG, Worm B, Harley SJ, Doherty PA (2003) Collapse and conservation of shark populations in the Northwest Atlantic. Science 299: 389-392

Braccini M, Van Rijn J, Frick L (2012) High post-capture survival for sharks, rays and chimaeras discarded in the main shark fishery of Australia? PLoS One 7:e32547

Brewster-Geisz KK, Miller TJ (2000) Management of the sandbar shark, Carcharhinus plumbeus: implications of a stage-based model. Fish Bull 98:236-249

Broadhurst MK, Butcher PA, Millar RB, Marshall JE, Peddemors VM (2014) Temporal hooking variability among sharks on south-eastern Australian demersal longlines and implications for their management. Global Ecol Conserv 2:181-189

Butcher PA, Broadhurst MK, Orchard BA, Ellis MT (2010) Using biotelemetry to assess the mortality and behaviour of yellowfin bream (Acanthopagrus australis) released with ingested hooks. ICES J Mar Sci 67:1175-1184 
Butcher P, Peddemors V, Mandelman J, McGrath S, Cullis B (2015) At-vessel mortality and blood biochemical status of elasmobranchs caught in an Australian commercial longline fishery. Global Ecol Conserv 3:878-889

Campana SE, Dorey A, Fowler M, Joyce W, Wang Z, Wright D, Yashayaev I (2011) Migration pathways, behavioural thermoregulation and overwintering grounds of blue sharks in the Northwest Atlantic. PLoS One 6:e16854

Compagno L (1984) FAO species catalogue, Vol. 4. Part 2: Sharks of the world: an annotated and illustrated catalogue of sharks species known to date. FAO Fish Synop 125. FAO, Rome

Conrath CL, Musick JA (2008) Investigations into depth and temperature habitat utilization and overwintering grounds of juvenile sandbar sharks, Carcharhinus plumbeus: the importance of near shore North Carolina waters. Environ Biol Fishes 82:123-131

> Daly-Engel TS, Grubbs RD, Bowen BW, Toonen RJ (2007) Frequency of multiple paternity in an unexploited tropical population of sandbar sharks (Carcharhinus plumbeus). Can J Fish Aquat Sci 64:198-204

> Domeier ML, Nasby-Lucas N (2008) Migration patterns of white sharks Carcharodon carcharias tagged at Guadalupe Island, Mexico, and identification of an eastern Pacific shared offshore foraging area. Mar Ecol Prog Ser 370:221-237

Domeier ML, Kiefer D, Nasby-Lucas N, Wagschal A, O'Brien F (2005) Tracking Pacific bluefin tuna (Thunnus thynnus orientalis) in the northeastern Pacific with an automated algorithm that estimates latitude by matching sea-surface-temperature data from satellites with temperature data from tags on fish. Fish Bull 103:292-306

> Dulvy NK, Baum JK, Clarke S, Compagno LJV and others (2008) You can swim but you can't hide: the global status and conservation of oceanic pelagic sharks and rays. Aquat Conserv 18:459-482

Frisk MG, Miller TJ, Fogarty MJ (2001) Estimation and analysis of biological parameters in elasmobranch fishes: a comparative life history study. Can J Fish Aquat Sci 58: 969-981

> Geraghty PT, Williamson JE, Macbeth WG, Blower DC and others (2014) Genetic structure and diversity of two highly vulnerable carcharhinids in Australian waters. Endang Species Res 24:45-60

Gilman E, Clarke S, Brothers N, Alfaro-Shigueto J and others (2008) Shark interactions in pelagic longline fisheries. Mar Policy 32:1-18

Gilman E, Suuronen P, Hall M, Kennelly S (2013) Causes and methods to estimate cryptic sources of fishing mortality. J Fish Biol 83:766-803

Grubbs RD, Musick J, Conrath CL, Romine JG (2007) Longterm movements, migration, and temporal delineation of a summer nursery for juvenile sandbar sharks in the Chesapeake Bay region. Am Fish Soc Symp 50:87-107

- Hammerschlag N, Gallagher AJ, Lazarre DM (2011) A review of shark satellite tagging studies. J Exp Mar Biol Ecol 398:1-8

Harrison J (2010) A socio-economic evaluation of the commercial fishing industry in the Ballina, Clarence and Coffs Harbour regions. Professional Fishermen's Association, FRDC Project No. 2009/054, Maclean, NSW

Harry AV, Tobin AJ, Simpfendorfer CA, Welch DJ and others (2011) Evaluating catch and mitigating risk in a multispecies, tropical, inshore shark fishery within the Great Barrier Reef World Heritage Area. Mar Freshw Res 62:
$710-721$

Hazin FH, Oliveira PG, Macena BC (2007) Aspects of the reproductive biology of the sandbar shark, Carcharhinus plumbeus (Nardo, 1827), in coastal waters off Pernambuco, Brazil. Col Vol Sci Pap ICCAT 60:629-635

Heupel MR, Semmens JM, Hobday AJ (2006) Automated acoustic tracking of aquatic animals: scales, designs and deployment of listening station arrays. Mar Freshw Res 57:1-13

> Hoffmayer E, Franks J, Driggers W III, McKinney J, Hendon J, Quattro J (2014) Habitat, movements and environmental preferences of dusky sharks, Carcharhinus obscurus, in the northern Gulf of Mexico. Mar Biol 161:911-924

Hoolihan JP, Luo J, Abascal FJ, Campana SE and others (2011) Evaluating post-release behaviour modification in large pelagic fish deployed with pop-up satellite archival tags. ICES J Mar Sci 68:880-889

Hueter R, Heupel M, Heist E, Keeney D (2005) Evidence of philopatry in sharks and implications for the management of shark fisheries. J Northwest Atl Fish Sci 35:239-247

Hussey NE, McCarthy ID, Dudley SFJ, Mann BQ (2009) Nursery grounds, movement patterns and growth rates of dusky sharks, Carcharhinus obscurus: a long-term tag and release study in South African waters. Mar Freshw Res 60:571-583

Joung SJ, Chen CT (1995) Reproduction in the sandbar shark, Carcharhinus plumbeus, in the waters off northeastern Taiwan. Copeia 1995:659-665

Kohler NE, Casey JG, Turner PA (1998) NMFS Cooperative Shark Tagging Program, 1962-93: an atlas of shark tag and recapture data. Mar Fish Rev 60:1-87

> Lam CH, Nielsen A, Sibert JR (2010) Incorporating sea-surface temperature to the light-based geolocation model TrackIt. Mar Ecol Prog Ser 419:71-84

Last PR, Stevens JD (2009) Sharks and rays of Australia, 2nd edn. CSIRO Publishing, Collingwood

Macbeth WG, Geraghty PT, Peddemors VM, Gray CA (2009) Observer-based study of targeted commercial fishing for large shark species in waters off northern New South Wales. Industry and Investment NSW - Fisheries Final Report Series No. 114. www.dpi.nsw.gov.au/ research/areas/fisheries-and-ecosystems/wild-fisheries/ outputs/2009/1600

McAuley R, Simpfendorfer C, Hyndes G, Lenanton R (2007) Distribution and reproductive biology of the sandbar shark, Carcharhinus plumbeus (Nardo), in Western Australian waters. Mar Freshw Res 58:116-126

McElroy WD, Wetherbee BM, Mostello CS, Lowe CG, Crow GL, Wass RC (2006) Food habits and ontogenetic changes in the diet of the sandbar shark, Carcharhinus plumbeus, in Hawaii. Environ Biol Fishes 76:81-92

Morgan A, Cooper P, Curtis T, Burgess GH (2009) An overview of the United States east coast bottom longline shark-fishery, 1994-2003. Mar Fish Rev 71:23-38

Musick JA (1999) Life in the slow lane: ecology and conservation of long-lived marine animals. In: Musick JA (ed) Life in the slow lane: ecology and conservation of longlived marine animals. Am Fish Soc Symp 23:1-10

Musick JA (2004) Introduction: management of sharks and their relatives (Elasmobranchii), Chap 1. In: Musick JA, Bonfil R (eds) Management techniques for elasmobranch fisheries. FAO Fish Tech Pap 474:1-5

> Musyl M, Domeier M, Nasby-Lucas N, Brill R and others (2011) Performance of pop-up satellite archival tags. Mar Ecol Prog Ser 433:1-28 
Nielsen A, Sibert JR (2007) State-space model for lightbased tracking of marine animals. Can J Fish Aquat Sci 64:1055-1068

Papastamatiou YP, Wetherbee BM, Lowe CG, Crow GL (2006) Distribution and diet of four species of carcharhinid shark in the Hawaiian Islands: evidence for resource partitioning and competitive exclusion. Mar Ecol Prog Ser 320:239-251

Portnoy DS, McDowell JR, Heist EJ, Musick JA, Graves JE (2010) World phylogeography and male-mediated gene flow in the sandbar shark, Carcharhinus plumbeus. Mol Ecol 19:1994-2010

Pratt H Jr, Carrier J (2001) A review of elasmobranch reproductive behavior with a case study on the nurse shark, Ginglymostoma cirratum. Environ Biol Fishes 60:157-188

Queiroz N, Humphries NE, Noble LR, Santos AM, Sims DW (2012) Spatial dynamics and expanded vertical niche of blue sharks in oceanographic fronts reveal habitat targets for conservation. PLoS One 7:e32374

Rechisky EL, Wetherbee BM (2003) Short-term movements of juvenile and neonate sandbar sharks, Carcharhinus plumbeus, on their nursery grounds in Delaware Bay. Environ Biol Fishes 68:113-128

Reynolds JD, Dulvy NK, Goodwin NB, Hutchings JA (2005) Biology of extinction risk in marine fishes. Proc R Soc B 272:2337-2344

Rogers PJ, Huveneers C, Goldsworthy SD, Mitchell JG, Seuront L (2013) Broad-scale movements and pelagic habitat of the dusky shark Carcharhinus obscurus off Southern Australia determined using pop-up satellite archival tags. Fish Oceanogr 22:102-112

Romine JG, Grubbs RD, Musick JA (2006) Age and growth of the sandbar shark, Carcharhinus plumbeus, in Hawaiian waters through vertebral analysis. Environ Biol Fishes 77:229-239

Romine JG, Musick JA, Burgess GH (2009) Demographic analyses of the dusky shark, Carcharhinus obscurus, in the Northwest Atlantic incorporating hooking mortality estimates and revised reproductive parameters. Environ Biol Fishes 84:277-289

Royer F, Lutcavage M (2009) Positioning pelagic fish from sunrise and sunset times: complex observation errors call for constrained, robust modelling. In: Neilsen JL, Arrizabalaga H, Fragoso N, Hobday A, Lutcavage M, Sibert J (eds) Tagging and tracking of marine animals with electronic devices. Reviews: methods and technologies in

Editorial responsibility: Steven Cooke, Ottawa, Ontario, Canada fish biology and fisheries, Vol 9. Springer, Dordrecht, p 323-341

Royer F, Fromentin JM, Gaspar P (2005) A state-space model to derive bluefin tuna movement and habitat from archival tags. Oikos 109:473-484

Sigler MF (2000) Abundance estimation and capture of sablefish (Anoplopoma fimbria) by longline gear. Can J Fish Aquat Sci 57:1270-1283

Simpfendorfer CA (1999) Demographic analysis of the dusky shark fishery in southwestern Australia. In: Musick JA (ed) Life in the slow lane: ecology and conservation of long-lived marine animals. Am Fish Soc Symp 23:149-160

Simpfendorfer CA, Goodreid A, McAuley RB (2001) Diet of three commercially important shark species from Western Australian waters. Mar Freshw Res 52:975-985

Simpfendorfer CA, McAuley RB, Chidlow J, Unsworth P (2002) Validated age and growth of the dusky shark, Carcharhinus obscurus, from Western Australian waters. Mar Freshw Res 53:567-573

Skomal GB (2007) Evaluating the physiological and physical consequences of capture on post-release survivorship in large pelagic fishes. Fish Manag Ecol 14:81-89

Sminkey TR, Musick JA (1995) Age and growth of the sandbar shark, Carcharhinus plumbeus, before and after population depletion. Copeia 1995:871-883

Smith SE, Au DW, Show C (1998) Intrinsic rebound potentials of 26 species of Pacific sharks. Mar Freshw Res 49: 663-678

Speed CW, Field IC, Meekan MG, Bradshaw CJA (2010) Complexities of coastal shark movements and their implications for management. Mar Ecol Prog Ser 408: 275-293

Stevens JD, Bonfil R, Dulvy NK, Walker PA (2000) The effects of fishing on sharks, rays, and chimaeras (chondrichthyans), and the implications for marine ecosystems. ICES J Mar Sci 57:476-494

Teo SLH, Boustany A, Blackwell S, Walli A, Weng KC, Block BA (2004) Validation of geolocation estimates based on light level and sea surface temperature from electronic tags. Mar Ecol Prog Ser 283:81-98

Violetta G (2004) Physical examination of elasmobranchs. In: Smith M, Warmolts D, Thoney D, Hueter R (eds) The elasmobranch husbandry manual: captive care of sharks, rays and their relatives. Ohio Biological Survey, Columbus, OH, p 271-280

Submitted: June 3, 2015; Accepted: March 16, 2016

Proofs received from author(s): May 23, 2016 